\title{
Stormwater Management Practices and Green-Blue Infrastructure in Urban Areas: an Overview
}

\author{
Department of Architecture and Design (DAD), University of Genova (Italy) paola.sabbion@gmail.com
}

\section{Introduction}

Growing urbanisation has dramatic impacts on water cycle, causing pollution, biodiversity loss and soil erosion worldwide. Indeed, healthy hydrological systems is able to retain water, regulate stormwater runoff and allow for groundwater recharge. In natural conditions rain permeats into the ground and gradually filters into rivers and groundwater. Leaves, branches, shrubs and soil retain water and slow water flow. On the contrary, impervious urban surfaces often act as an umbrella, increasing stormwater runoff. Water cannot be absorbed by impervious surfaces such as asphalt and concrete and it directly runs into rivers through drainage systems (Dunnett and Kingsbury, 2008). Thus, water tends to flow faster due to lower permeability which cause the quantity and rate of surface runoff to increase, hydrogeological instability and flooding risk (Shuster et al., 2005). In cities about $75 \%$ of rainfall is lost directly due to surface runoff compared with an estimated $5 \%$ loss in forested areas (ScholzBarth, 2001). Polluted stormwater runoff from urban areas affects the quality of waterbodies. Water pollution causes public and environmental health hazards, such as reduced drinking water quality and unsafe swimming water (EPA, 2016).

\section{Stormwater management: approaches and strategies}

Stormwater management is among the most important issues that needs to be addressed in urban areas.
Conventional stormwater management approaches have often failed to pursue environmental preservation due to the incapacity to address the variations to the flow regime caused by conventional drainage. Moreover, water coming into contact with anthropic surfaces collects toxic substances and pollutants that have a negative impact on ecosystems. For this reason, it is urgent to "ensure that the good status of surface water and groundwater is achieved and that deterioration in the status of waters is prevented" (European Parliament, 2000).

In the United States, the Clean Water Act and successive amendments have governed water pollution, restoring and maintaining chemical, physical, and biological integrity of waters. In Europe, the European Union has recently established the need to pursue the preservation, protection and improvement of the environmental quality and the rational use of water. Innovative aspects of the current European legislation are included in the Framework Directive 60/2000 (European Parliament, 2000) and in the Directive on the Protection of Underground Waters (2006/118/EC). These regulate the integration of management policies on drinking water, bathing, surface and groundwater; water alteration control; definition of environmental quality standards; and identification of significant trends of deterioration/recovery of water bodies. This new regulatory framework outlines quality improvement objectives, defining also ecological aspects

\begin{abstract}
Water quality, flooding risk, and water consumption in urban areas are emerging issues. Urban impervious surfaces increase stormwater runoff, affecting ecosystems and leading to hydrogeological instability and flooding risk. Sustainable urban design strategies can contribute to counteract the negative impact of anthropic activities both at city-scale and global scale. Green and Blue Infrastructure (GBI) approaches, in particular, are an alternative to stormwater traditional management. In Europe, Sustainable Drainage System implementation copes with impervious surfaces to achieve water quality, amenity, and biodiversity increase. Best Management Practices, developed mainly in the USA, focus on specific measures for sustainable stormwater treatment. Water Sensitive Urban Design, spread in Australia and England, also aims to minimise the impact of developed areas preventing flood risk, limiting water consumption and enhancing environmental quality. In the USA and Canada, Low Impact Development offers design strategies to manage runoff and deliver structural practices to mimic predevelopment processes of infiltration, filtration and detention.
\end{abstract}

Key words: Green and Blue Infrastructure; stormwater approaches; Best Management Practices; Water Sensitive Urban Design; Low Impact Development; Sustainable Drainage Systems

Published online: 31st January, 2018

as well as chemical aspects. Moreover, during the last decades, a transition from 
conventional engineering-based water management to eco-system preservation and restoration has occurred. New approaches imitate undeveloped catchment areas, shifting from water drainage to slower flows and increased permeability. Successful urban planning reduces stormwater runoff, integrating green and blue techniques as infiltration, vegetative uptake and evapotranspiration. In this framework, the use of Green and Blue Infrastructure (GBI) can improve water quality while reducing stormwater runoff. Vegetation in metropolitan areas can provide a wide range of benefits, enhancing human wellbeing and environmental conditions by acting on both causes and effects.

Approaches and strategies have emerged at various scales and worldwide (Sustainable Drainage Systems in Europe, Best Management Practices in USA and Canada, Water Sensitive Urban Design in Australia, Low Impact Development in USA, etc.). These strategies all follow an approach that tends to integrate $\mathrm{GBI}$ implementation with urban planning. New approaches focus on lower-risk areas, local collection and distribution, slower flows, and increased permeability. Urban planning employs these practices across various spatial scales oriented to the restoration of river basins and wetlands and the design of habitat corridors (Barton et al., 2015).

As stated by the OECD, UNEP and EU, urban settlements should be adjusted in relation to natural capital and climate change mitigation to lower the threats to hydro-morphology and decrease the impact of floods and droughts on human settlements. Source control techniques for detention/retention of stormwater runoff through infiltration, vegetative uptake and evapotranspiration can reduce the need for stormwater storage and treatment systems. There are several cities, around the world, where trans-disciplinary conservation of urban ecosystem services and water management are the foundation of urban design. $\mathrm{GBI}$ incorporation not only enhances the capacity of these cities to supply water and prevent flooding, but also provides health benefits and a better quality of life. Cities worldwide are focusing on key redevelopment projects, such as enhancing the quality of accessible waterways. It has enhanced the construction of new public spaces, often recovering post-industrial and port areas. Restoring urban water systems can be achieved by planning new systems of infiltration, retention, evapotranspiration and water control, through the selection of vegetation and the correct application of compatible construction techniques. This type of recovery addresses the specific hydrological problems of each city, without neglecting formal and spatial dimensions (Perini, Sabbion 2017).

In this framework, green and blue infrastructure (GBI) can join management practices to increase the quality of the urban environment and prevent the risk of flooding. GBI can, in fact, reduce stormwater runoff at the catchment and neighbourhood scales. $\mathrm{GBI}$ is among the main strategies implemented for urban sustainability. Special attention is given to the so-called Water Sensitive Design, a series of strategies developing innovative solutions for the management of rainwater and surface runoff water in urban areas. Water Sensitive Design strategies include the use of $\mathrm{GBI}$ and natural elements to improve the relationship between the water system and urbanised areas. The following are the most widespread guidelines for GBI implementation: Sustainable Drainage System (in Europe), Best Management Practices (in USA), Water Sensitive Urban Design (in Australia and England), Low Impact Development (in USA and Canada).

\section{Sustainable drainage system (SuDS)}

Sustainable Drainage System (SuDS) approach is the most disseminated water management method in Europe, starting from England. The Water Management Act of 2010 established that SuDS would fully replacing conventional management systems in UK. The National Standards for Sustainable Drainage (DEFRA-Department for Environment, Food and Rural Affairs, 2011) support this change, and help designers and authorities to respect the requirements.

SuDS guidelines have been developed to control the negative impact of urbanisation on natural water cycle. SuDS strategies intend to simulate the natural drainage occurring in pre-development conditions through runoff attenuation and infiltration, filtering pollutants, and creating attractive environments for communities. Sustainability is central to this approach. This concept considers water as a tool to achieve other benefits including environmental, social and economic aspects (Mazzarello and Raimondo, 2015; Dickie et al., 2010; Ballard et al., 2007). In particular, the SuDS method considers three aspects: water quality, water quantity, and amenity/biodiversity: the so-called "SuDS triangle".

The components for the SuDS system must be chosen and fitted following a series of evaluations and analyses. Performances of SuDS depend on a number of specific considerations such as the use of appropriate plants, attention in protecting the system from debris, and care in the integration with the surrounding landscape (Ballard et al., 2007).

Treatment trains are among the most important SuDs strategies. These are a set of drainage techniques arranged in hierarchical series of several steps. The first is prevention in terms of house site design to reduce runoff 
and pollution and collection/stormwater reuse techniques. The second step regards source control, managing runoff components (porous paving green roofs, etc.). The third step involves local control of infiltration or detention systems, including swales, detention basins, etc. The fourth and last step refers to regional control, including largescale components such as ponds and wetlands (Dickie et al., 2010). The connections between the individual parts of a treatment train must be guaranteed by the use of natural conveying components, such as depressions in the ground or filter trenches.

\section{Best management practices (BMPs)}

Best Management Practices (BMPs) include a series of stormwater approaches, which are widespread especially in the United States. BMPs are based on the application of a number of control techniques targeting interventions on the quantity and quality of stormwater runoff. BMPs also facilitate water collection and reuse, ensuring the hydraulic invariance of surface runoff and increasing infiltration into the soil (IOWA Department of Natural Resources, 2009).

BMPs include non-structural methods, which can reduce surface runoff and pollution derived from runoff and structural controls which are used to manage and treat runoff. Non-structural BMPs include normative, regulatory, and educational guidelines for land-use planning to limit the conversion of rain in runoff, with subsequent impacts on the territory. These solutions are identified with Stormwater Better Site Design Practices, precisely because they are applied at a planning phase, in particular for new developments.

Structural BMPs, are focused on strategies and techniques for stormwater treatment at the beginning of the drainage system to intercept the rainfall on the ground. The main purposes of
BMPs include: surface flow speed control; reduction of runoff volume from urbanised areas; and reduction of pollutant and contaminant sources. Some structural measures can be used in a wide variety of situations, without strictly depending from the context. They are able to satisfy all the qualitative and quantitative management objectives and include: ponds, wetlands, bioretention areas, sand filters, infiltration trenches, and swales. Other structural measures are recommended only for specific sites conditions (i.e. commercial, industrial or institutional areas). They include the implementation of filter strips, grass channels, and porous paver systems (Atlanta Regional Commission, 2014).

\section{Water sensitive urban design (WSUD)}

Water Sensitive Urban Design is an approach developed in the 1990s in Australia and then implemented in England to protect water resources. Its main goal is to minimise the negative impact on the water cycle simulating the natural drainage system by acting on runoff source (Department of the Environment, 2009). The integration of planning and stormwater management has additional benefits regarding urban quality increase. Each WSUD initiative is guided by the key principles of sustainability, such as limiting potable water consumption, recycling, minimising water waste and enhancing water-efficient landscaping.

WSUD strategies provide for water detention, storage and infiltration. Control features are grouped by the degree of guaranteed purification, e.g. by the size of the pollutants that are retained. Primary treatment provides a physical selection that allows removing floating materials, coarse sediments, and oils (e.g. grassed swales and sediment basins). Secondary treatment includes sedimentation components for finer particles and filtration (e.g. permeable pavements, vegetated filter strips, vegetated swales, infiltration systems, and bioretention systems). Tertiary treatment provides advanced biological absorption thanks to sedimentation and filtration for heavy metals and bacteria (e.g. wetlands and ponds) (Department of the Environment, 2009).

In Australia, as in the USA for BMPs, each region has developed its own system of WSUD. Regional manuals, although, provide a certain uniformity of content thanks to the national reference guide Evaluating Options for Water Sensitive Urban Design (Department of the Environment, 2009). Its key principles regard the reduction of potable water demand for non-drinking purposes, water quality improvement for reuse, and the restoration of catchments' natural hydrological regime. Furthermore, different types of manuals have been created for every category of users, from citizens to designers and constructors. This model of design approach and the dissemination of stormwater management practices is aimed at integrating different levels of planning, from the smallest neighbourhood scale to the regional one. Great importance is also given to the maintenance of the systems (Greater Sydney Local Land Services, 2014).

\section{Low impact development (LID)}

Low Impact Development (LID) was implemented in the USA, since the 1990s, along with BMPs, as an alternative to traditional stormwater management systems. LID is also used in Canada (Toronto and Region Conservation Authority, 2010). This approach includes a number of techniques acting on the control of pollutants, volume reduction, runoff speed, and flood control. LID includes a set of site design strategies to minimise runoff and distribute small-scale structural practices that mimic predevelopment

hydrology 
through the processes of infiltration, evapotranspiration, filtration and detention of stormwater (United States Environmental Protection Agency, 2007). Each State requires all property owners to outline a Stormwater Management Plan (SWMP) to meet these requirements to tackle the increase of impervious surfaces due to urban development.

The Low Impact Development approach, therefore, mimics the natural cycle, controlling runoff at the source, using micro-scale checks distributed throughout the catchment. LID infiltrate rainwater using the characteristics of the soil and permeable surfaces, thus reducing runoff volumes and filtering water before it runs away from the place where it was produced. Since LID practices are environmentally friendly structural controls, they can be considered part of the BMPs. In particular, BMPs were developed in the United States to address the issues arising from small-scale events, considering all ecological benefits or enjoyment as an added value. The LID approach, on the other hand, was created to manage the outflows arising from events of any size and quality in an urban context (Ferrier and Jenkins, 2009).

\section{Conclusion}

GBI implementation policies should focus on long-term achievements, sustainable renewal of the urban environment, setting policy priorities and investments. The preservation of water-related environmental, recreational and cultural values is a further objective of GBI approach, achieved by minimising the ecological footprint of waterrelated projects. Such operations require a series of complex actions and planning to trigger an effective change. Indeed, the success of such virtuous systems depends on the efficient use of financial resources, and the ability to engage communities in a shared program (Feyen et al. (eds.), 2008). Therefore, finding financial resources for $\mathrm{GBI}$ implementation presents a challenge but, at the same time, the improvement of natural resources represents a new opportunity for the sustainable development of urban systems.

\section{References:}

Atlanta Regional Commission. (2014). Georgia Stormwater Management Manual. [Online]. Available at: http://www.atlantaregional.com/e nvironment/georgia-stormwatermanual [Accessed: 6 June 2016].

Ballard, B. W., Kellagher, R., Martin, P., Jefferies, C., Bray, R. and Shaffer, P. (2007). Site Handbook for the Construction of SUDS. CIRIA [Online]. Available at: http://www.orkneywind.co.uk/adv ice/SEPA\%20Pollution\%20Advice/c iria\%20c698.pdf [Accessed: 7 June 2016].

Barton, H., Thompson, S., Burgess, S. and Grant, M. (2015). The Routledge Handbook of Planning for Health and Well-Being: Shaping a sustainable and healthy future. Routledge.

DEFRA-Department for Environment, Food and Rural Affairs. (2011). National Standards for sustainable drainage systems Designing, constructing, operating and maintaining drainage for surface runoff. [Online]. Available at:

https://www.gov.uk/government/ uploads/system/uploads/attachm ent_data/file/82421/suds-consultannexa-national-standards-

111221.pdf [Accessed: 7 June 2016].

Department of the Environment. (2009). Evaluating options for water sensitive urban design $-a$ national guide. Text. [Online]. Available at: https://www.environment.gov.au/ resource/evaluating-optionswater-sensitive-urban-design\%E2\%80\%93-national-guide [Accessed: 6 June 2016].

Dickie, S., McKay, G., Ions, L. and Shaffer, P. (2010). Planning for SuDS - making it happen. CIRIA. [Online]. Available at: http://www.eastcambs.gov.uk/site
s/default/files/C687\%20Planning\% 20for\%20suds.pdf.pdf [Accessed: 7 June 2016].

Dunnett, N. and Kingsbury, N. (2008). Planting green roofs and living walls. Portland, Or.: Timber Press.

EPA, U. (2016). US Environmental Protection Agency. [Online]. Available at: http://www3.epa.gov/ [Accessed: 12 February 2016].

European Parliament. (2000). Directive 2000/60/EC of the European Parliament and of the Council of 23 October 2000 establishing a framework for Community action in the field of water policy.

Everett, G. and Lamond, J. (2014). A conceptual framework for understanding behaviours and attitudes around 'Blue-Green' approaches to Flood-Risk Management. In: 18 June 2014, p.101-112. [Online]. Available at: doi:10.2495/FRIAR140091

[Accessed: 15 December 2015].

Ferrier, R. C. and Jenkins, A. (2009). Handbook of Catchment Management. John Wiley \& Sons.

Feyen, J., Shannon, K. and Neville, M. (eds.). (2008). Water and Urban Development Paradigms: Towards an Integration of Engineering, Design and Management Approaches. 1 edition. Boca Raton, Fla.; London: CRC Press.

Greater Sydney Local Land Services. (2014). Water Sensitive Urban Design. [Online]. Available at: http://www.wsud.org/.

IOWA Department of Natural Resources. (2009). lowa Stormwater Management Manual. IOWA DNR. [Online]. Available at: http://www.iowadnr.gov/Environ mental-Protection/Water-

Quality/NPDES-Storm-

Water/Storm-Water-Manual

[Accessed: 6 June 2016].

Mazzarello, M. and Raimondo, M. (2015). Infrastrutture verdi: una gestione alternativa delle acque meteoriche. Genova, verso una 'Water Sensitive City'. Università degli Studi di Genova Scuola Politecnica: Dipartimento di 
Scienze per l'Architettura.

Perini K., Sabbion P. (2017), Urban

Sustainability and River

Restoration: Green and Blue Infrastructure,Wiley Blackwell John Wiley \& Sons, LondonNewYork.

Scholz-Barth, K. (2001). Green Roofs: Stormwater Management from the Top Down. Environmental Design \& Construction, Feature, January/February 2001. [Online]. Available at: http://www.usgbccc.org/documen ts/StormWaterManagement.pdf [Accessed: 30 January 2014].

Shuster, W. D., Bonta, J., Thurston, H., Warnemuende, E. and Smith, D. R. (2005). Impacts of impervious surface on watershed hydrology: A review. Urban Water Journal, 2 (4), p.263-275. [Online]. Available at: doi:10.1080/15730620500386529.

Toronto and Region Conservation Authority (2010). Low impact development stormwater management planning and design guide. Version 1.0. [Online]. Available at: http://www.creditvalleyca.ca/wpcontent/uploads/2014/04/LIDSWM-Guide-v1.0_2010_1_noappendices.pdf [Äccessed: 7 June 2016].

Van Roon, M. (2005). Emerging approaches to urban ecosystem management: The potential of low impact urban design and development principles. Journal of Environmental Assessment Policy and Management, 7 (1), p.125148. Scopus [Online]. Available at: doi:10.1142/S1464333205001943.

United States Environmental Protection Agency. (2007). Reducing Stormwater Costs through Low Impact Development (LID) Strategies and Practices. Report No. EPA 841-F-07-006. Washington, D.C. [Online]. Available at: http://www.creditvalleyca.ca/wpcontent/uploads/2012/02/lidswm-guide-chapter1.pdf. 